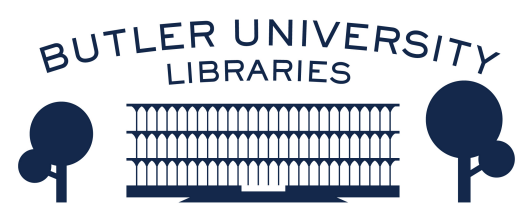

Journal of Hindu-Christian Studies

\title{
Book Review: The Truth Within: A History of Inwardness in Christianity, Hinduism, and Buddhism
}

Holly Hillgardner

Bethany College

Follow this and additional works at: https://digitalcommons.butler.edu/jhcs

\section{Recommended Citation}

Hillgardner, Holly (2015) "Book Review: The Truth Within: A History of Inwardness in Christianity, Hinduism, and Buddhism," Journal of Hindu-Christian Studies: Vol. 28, Article 18.

Available at: https://doi.org/10.7825/2164-6279.1617

The Journal of Hindu-Christian Studies is a publication of the Society for Hindu-Christian Studies. The digital version is made available by Digital Commons @ Butler University. For questions about the Journal or the Society, please contact cbauman@butler.edu. For more information about Digital Commons @ Butler University, please contact digitalscholarship@butler.edu. 
those who prefer tight boundaries and a measure of control, whether doctrinal or ideological. But, as the adage goes, the cat is out of the bag. The empirical record testifies to the fact that religions typically change-just as everything else changesunder specific conditions, including, here, historical and social conditions. The beauty of Gleig's and Williamson's book is its careful and detailed accounting of that phenomenon as Hinduism, after washing across the shores of America with earlier gurus, took root and grew in specific and innovative ways under the charisma and creativity of America's own homegrown gurus.

Thomas A. Forsthoefel

Mercyhurst University

\section{The Truth Within: A History of Inwardness in Christianity, Hinduism, and Buddhism Gavin Flood. Oxford: Oxford University Press, 2013, xviii + 310 pages.}

A sense of religious inwardness persists, even after such philosophical game-changers as the deconstruction of the privileged subject and the demise of cosmology. What can we make of this persistent, maybe even perennial, inwardness? In his careful study of the medieval religions of Europe and South Asia, Gavin Flood uncovers collective, cosmological senses of inwardness and inquires about their implications for religious studies today.

In this ambitious book, Flood's reach is thrillingly wide: three world religionsChristianity, Buddhism, and Hinduism, throughout the Middle Ages, across Europe and South Asia. After surveying the concept of the truth within in Hinduism, Buddhism, and Christianity in Part I, Part II draws on part I to develop a theory of religious inwardness while addressing critiques that emerge.

The book examines the metaphor of interiority and explores the relation of interior truth to ideas of the self. Flood's previous book,
The Ascetic Self: Subjectivity, Memory and Tradition (2004) explored how asceticism functions to intensify subjectivity while decreasing individuality; that is, the practitioner becomes embedded more deeply in the cosmos and in religious history. The intensification of subjectivity in the ascetic self, while being an erosion of individuality, is not thereby a depersonalization. He refines these ideas further in The Truth Within when he trenchantly names the practices and traditions of inwardness a "transcendence of restriction" (193). Inwardness as a shared subjectivity thus differs from individualism "where individualism is a kind of social value that emphasizes the particular carrier of the 'I' as self-assertion against the social group" (194). He claims that human subjectivity is cultivated in all three religions through their respective spiritual practices, but he distinguishes this subjectivity from "the kind of private, romantic inwardness we are familiar with in late 
modernity"(xii). Inwardness is not individualism, Flood notes multiple times, and it bears repeating to our modern/postmodern ears. His careful focus on medieval notions of shared/collective subjectivity helps readers understand these important differences.

The book also serves as a persuasive refutation of some common critiques lobbed against the whole field of comparative religion. I expected Flood to foreground such tricky concerns, but he leaves most of the theoretical underpinnings of the book unstated until the final chapter. In this refreshing structure, he instead focuses on performing a cogent, nuanced comparative religion. Regarding the similarities he traces amongst the three religions, he does not claim that the content of the various texts is the same or that the Other to which texts refer is the same; instead, he asserts that they "share a structure of subjectivity in which an intensification of inwardness is understood as an internal journey to inner transcendence and the truth within: they share an inner cosmological world view" (195). Thus comparison proceeds.

Flood employs a two-level structure to the book, which purports to appeal to both specialists and non-specialists. Because of its wide-ranging interdisciplinarity, it is unlikely that any one reader would be expert in all the fields and subfields included. One probably would, however, need to be a specialist in something related-philosophy, religion, medieval history, philosophy of religion, Sanskrit, phenomenology, sociology, semiotics-to make one's way meaningfully through this book's complexity.

Much of today's comparative work focuses on two religious traditions, so Flood's choice to work with a third tradition, Buddhism, raises the question of what its inclusion contributes. Most obviously, Buddhism provides another opportunity to pile up more examples of inwardness. Including Buddhism in this study also complicates some of the categories Flood uses, such as the self, an acknowledged concern from which he does not shy away. He takes care to show how Buddhism, too, in its own distinct way, develops the idea of the truth within, even as it deconstructs the metaphysics of the self.

One technique for reducing ethnocentric bias in East/West comparison involves beginning with the Eastern traditions, thus setting up Christianity to be read through the lens of the Eastern religions, rather than starting with the assumptions and categories of Christianity. While Flood records the book's intellectual gestation as beginning with his contemplation of inwardness in Indian traditions, the actual structure of the book begins with readings of Christian texts and then moves on to Hindu and Buddhist ones, which might have been gainfully reversed.

Near the book's end, Flood proposes that thinking about religious inwardness can aid our thinking about politics, ethics, and interreligious interactions. What is the place of inwardness in the contemporary world, one in which cosmology has lost its grounding place? Restoring the sacredness of the human person without re-inscribing totalizing claims remains a great philosophical challenge. While he rightly emphasizes that social oppression-of women, GLBT persons, and the disabled, for example-is linked with an understanding of a social order based on hierarchical cosmologies, he also offers some intriguing preliminary attempts to discuss this project's constructive implications. For example, he notes cosmological subjectivity's ability to help 
interrogate our "contemporary social to love, a love where our limits are fragmentation" (269). He further proposes, "The collective subjectivity of the cosmological religions offers a potentially forceful model for human solidarity in the future" (Ibid.). How would such a collective subjectivity be reimagined for our age? Finally, he lauds the "imaginative space opened by religious inwardness in which forms of love are cultivated that takes us beyond our personal desires and in which awareness of death is our companion" (272). Here, Flood issues a compelling invitation to let inwardness open us acknowledged and others' desires may thrive.

Holly Hillgardner

Bethany College 